\title{
Oxidation of Benzyl Alcohols with Extraordinarily High Kinetic Isotope Effects ${ }^{\dagger}$
}

\author{
Myeong Ran Jo and Won K. Seok ${ }^{*}$ \\ Department of Chemistry, Dongguk University, Seoul 100-715, Korea. *E-mail: wonkseok@dongguk.edu \\ Received March 11, 2011, Accepted April 21, 2011
}

\begin{abstract}
Reactions of benzyl alcohol and its derivatives by $\left[\mathrm{Ru}^{\mathrm{IV}}(\mathrm{tpy})(\mathrm{dcbpy})(\mathrm{O})\right]^{2+}\left(\mathrm{tpy}=2,2^{\prime}: 6^{\prime}, 2^{\prime \prime}\right.$-terpyridine; dcbpy $=4,4^{\prime}$-dicarboxy-2,2'-bipyridine) leading to the corresponding benzaldehydes in acetonitrile and water have been studied. Kinetic studies show that the reaction is first-order in both alcohol and oxidant, with $k=1.65( \pm$ $0.1) \mathrm{M}^{-1} \mathrm{~s}^{-1}$ at $20^{\circ} \mathrm{C}, \Delta H^{*}=4.3( \pm 0.1) \mathrm{kcal} / \mathrm{mol}, \Delta S^{\sharp}=-22( \pm 1)$ eu, and $E_{\mathrm{a}}=4.9( \pm 0.1) \mathrm{kcal} / \mathrm{mol}$. High $\alpha \mathrm{C}-\mathrm{H}$ kinetic isotope effects are observed, but $\mathrm{O}-\mathrm{H}$ solvent isotope effects are negligible. Spectral evidences with the isotope effects suggest that oxidation of benzyl alcohols occurs by a two-electron, hydride transfer. The catalytic cycles of aerobic benzyl alcohol oxidation are employed.
\end{abstract}

Key Words : Ru oxo complex, Mechanisms, High kinetic isotope effects

\section{Introduction}

Oxidation reactions draw considerable interest for their importance in the manufacture of fine chemicals, sensors, and photoelectrochemical synthetic cells. ${ }^{1}$ Especially polypyridyl ruthenium oxo complexes have been proved to be versatile stoichiometric and/or catalytic oxidants toward organic and inorganic substrates via a variety of pathways that have been investigated in detail. ${ }^{2}$ The systems also disclosed previously undiscovered pathways for water oxidation. ${ }^{3}$

Attachment of reactive complexes on nanoparticle $\mathrm{TiO}_{2}$, $\mathrm{ZrO}_{2}$, and other oxide surfaces can be achieved through carboxylate or phosphate linkages. Especially, the carboxylate linkage strategy has been used to prepare optically transparent $\mathrm{TiO}_{2}$ nanoparticle films on glass or ITO electrodes containing surface-attached ruthenium dyes in dye-sensitized solar cells. ${ }^{4}$ To apply this approach for the preparation of the surface attached complex, glass $\mid \mathrm{TiO}_{2}-\left(\mathrm{HO}_{2} \mathrm{C}\right)_{2}$-bpy)(tpy)Ru $=\mathrm{O}]^{2+}\left(\right.$ tpy $=2,2^{\prime}: 6$ ',2"-terpyridine; $\left(\mathrm{HO}_{2} \mathrm{C}\right)_{2}$-bpy $=4,4^{\prime}$-dicarboxy-2,2'-bipyridine (dcbpy)), we promptly try to understand oxidative mechanisms of the ruthenium precursor.

Although oxidations of primary and secondary alcohols to aldehydes and ketones by oxidants have been reported, few mechanistic details are known. ${ }^{5}$ We report here the initial results of kinetics and reaction pathways on the oxidation of benzyl alcohol and its derivatives by $[\mathrm{Ru}(\mathrm{tpy})(\mathrm{dcbpy})(\mathrm{O})]^{2+}$. Our study has also applied to catalytic implication.

\section{Experimental Section}

Materials. $\mathrm{RuCl}_{3} \mathrm{xH}_{2} \mathrm{O}$ was purchased from the Aldrich Chemical Co. $\left(\mathrm{NH}_{4}\right)_{2}\left[\mathrm{Ce}\left(\mathrm{NO}_{3}\right)_{6}\right]$ was obtained from the Merck. $2,2^{\prime}: 6$ ',2"-terpyridine (tpy) was received from the Sigma and used without further purification. 4,4'-dimethyl-2,2'-bipyridine (dmbpy) was obtained from the Aldrich. Benzyl alcohol

This paper is dedicated to Professor Eun Lee on the occasion of his honourable retirement. from the Wako, 4-methoxybenzyl alcohol and 4-nitrobenzyl alcohol from the TCI and 2-ethylbenzyl alcohol from the Aldrich were purified using standard techniques. ${ }^{6}$ Dideuteriophenylcarbinol (benzyl alcohol- $\alpha, \alpha-d_{2}$ ) was obtained from Kanto Chemical Co. and the purity was verified by ${ }^{1} \mathrm{H}-\mathrm{NMR}$ spectrometer. Sealed ampoule $\mathrm{CD}_{3} \mathrm{CN}$ (99 atom \%), $\mathrm{D}_{2} \mathrm{O}$ (99.8 atom \%), $\left(\mathrm{CD}_{3}\right)_{2} \mathrm{CO}$ (99.9 atom \%), and $\mathrm{CD}_{3} \mathrm{OD}(99.5$ atom \%) were purchased from the Aldrich. Acetonitrile was obtained from Taijung Chemical Co. and was purified by distillation from $\mathrm{P}_{2} \mathrm{O}_{5}$ under an argon atmosphere. Water was purified by using a Nanopure ${ }^{\mathrm{TM}}$ water system. All other common reagents were ACS grade and were used without additional purification.

Preparations. [ $\left.\mathrm{Ru}(\mathrm{tpy}) \mathrm{Cl}_{3}\right]$ and 4,4'-dicarboxy-2,2'-bipyridine (dcbpy) were prepared by previously described procedures. $^{7}$

[Ru(tpy)(dcbpy)Cl](Cl). LiCl (20 mg, $2.17 \mathrm{mmol})$, dcbpy (62 $\mathrm{mg}, 0.26 \mathrm{mmol})$, and triethylamine $(200 \mu \mathrm{L}, 14.3 \mathrm{mmol})$ were added to a suspension of $\left[\mathrm{Ru}(\mathrm{tpy}) \mathrm{Cl}_{3}\right](110 \mathrm{mg}, 0.25$ $\mathrm{mmol})$ in ethanol $(30 \mathrm{~mL})$ and water $(10 \mathrm{~mL})$. The solution was refluxed for $8 \mathrm{~h}$ and the hot solution was filtered to remove unreacted reactants. The volume was reduced to $1 / 3$ on a rotatory evaporator. After refrigerating overnight, the product was collected on a medium frit and washed with icecold water $(2 \times 10 \mathrm{~mL})$ and washed again with diethyl ether $(3 \times 10 \mathrm{~mL})$ and dried at room temperature overnight. The product was recrystallized by dissolving it in $5 \mathrm{~mL}$ of methanol followed by dropping into $25 \mathrm{~mL}$ of diethyl ether. The crystalline product was filtered and dried in a vacuum dessicator. Yield: $60 \%$. Anal. Calc. for $\mathrm{C}_{27} \mathrm{H}_{19} \mathrm{~N}_{5} \mathrm{Cl}_{2} \mathrm{O}_{4} \mathrm{Ru}$ : C, 49.9; $\mathrm{H}$, 2.95; N, 10.8. Found: C, 48.7; H, 2.88; N, 10.4. UV-visible $\left(\mathrm{CH}_{3} \mathrm{OH}\right) \lambda_{\max }, \mathrm{nm}\left(\varepsilon, \mathrm{M}^{-1} \mathrm{~cm}^{-1}\right)=273(42,800), 307$ $(83,900), 360(15,500)^{\text {sh }}, 496(21,600) .{ }^{1} \mathrm{H}-\mathrm{NMR}, \mathrm{ppm}(200$ $\mathrm{MHz}, \mathrm{CD}_{3} \mathrm{OD}$ ): $\delta 10.20$ (dd, $J=5.8 \mathrm{~Hz}, 1 \mathrm{H}, 6$ of dcbpy), 9.15 (s, $1 \mathrm{H}, 3$ of dcbpy), 8.85 (s, $1 \mathrm{H} ; 3^{\prime}$ of dcbpy), 8.65 (d, $J$ $=8.0 \mathrm{~Hz}, 2 \mathrm{H}, 3^{\prime}$ and $5^{\prime}$ of tpy), $8.52(\mathrm{dd}, J=7.9 \mathrm{~Hz}, 2 \mathrm{H}, 3$ and 3" of tpy), 8.35 (dd, $J=5.6,1.6 \mathrm{~Hz}, 1 \mathrm{H}, 5$ of dcbpy), $8.16\left(\mathrm{t}, J=8.1 \mathrm{~Hz}, 1 \mathrm{H}, 4^{\prime}\right.$ of tpy), $7.93(\mathrm{dt}, J=7.9,1.6 \mathrm{~Hz}$, 
$2 \mathrm{H}, 4$ and 4" of tpy), 7.72 (d, $J=4.8 \mathrm{~Hz}, 1 \mathrm{H}, 5^{\prime}$ of dcbpy), 7.34 (m, 5H, 6' of dcbpy and 5, 5', 6, 6' of tpy).

[Ru(tpy)(dcbpy) $\left.\left(\mathbf{O H}_{2}\right)\right]\left(\mathbf{C l O}_{4}\right)_{2}$. $\mathrm{AgClO}_{4}(71 \mathrm{mg}, 0.34$ $\mathrm{mmol})$ was added into a solution of $[\mathrm{Ru}($ tpy $)(\mathrm{dcbpy}) \mathrm{Cl}](\mathrm{Cl})$ (55 mg, $0.08 \mathrm{mmol})$ in ethanol/water $(15: 5 \mathrm{v} / \mathrm{v})$. The deep purple reaction mixture was heated to reflux for $4 \mathrm{~h}$. After the precipitate was filtered off, the ethanol solvent was completely removed on a rotator evaporator. After refrigerating overnight, the crystalline product was filtered and dried in a vacuum dessicator. Yield: $50 \%$. Anal. Calc. for $\mathrm{C}_{27} \mathrm{H}_{21} \mathrm{~N}_{5} \mathrm{Cl}_{2} \mathrm{O}_{13} \mathrm{Ru}$ : C, 39.9; H, 2.85; N, 8.61. Found: C, $39.5 ; \mathrm{H}, 2.80 ; \mathrm{N}, 8.64$. UV-visible $\left(\mathrm{H}_{2} \mathrm{O}\right): \lambda_{\max }, \mathrm{nm}\left(\varepsilon, \mathrm{M}^{-1} \mathrm{~cm}^{-1}\right)$ $=273(60,800), 307(139,600), 357(22,400)^{\text {sh }}, 487(36,600)$. ${ }^{1} \mathrm{H}-\mathrm{NMR}$, ppm $\left(200 \mathrm{MHz}, \mathrm{D}_{2} \mathrm{O}\right): \delta 9.58(\mathrm{dd}, J=6.0 \mathrm{~Hz}, 1 \mathrm{H}$, 6 of dcbpy), 9.00 (s, 1H, 3 of dcbpy), 8.65 (s, 1H, 3' of dcbpy), 8.53 (d, $J=8.2 \mathrm{~Hz}, 2 \mathrm{H}, 3^{\prime}$ and $5^{\prime}$ of tpy), 8.39 (d, $J=$ $8.0 \mathrm{~Hz}, 2 \mathrm{H}, 3$ and 3" of tpy), 8.29 (d, $J=5.8 \mathrm{~Hz}, 1 \mathrm{H}, 5$ of dcbpy), 8.18 (t, $J=8.1 \mathrm{~Hz}, 1 \mathrm{H}, 4^{\prime}$ of tpy), 7.90 (t, $J=7.9 \mathrm{~Hz}$, $2 \mathrm{H}, 4$ and $4 "$ of tpy), 7.68 (d, $J=5.0 \mathrm{~Hz}, 2 \mathrm{H}, 6$ and $6 "$ of tpy), 7.44 (d, $J=6.0 \mathrm{~Hz}, 1 \mathrm{H}, 5^{\prime}$ of dcbpy), 7.22 (m, 3H, 6' of dcbpy and 5 and 5 " of tpy).

[Ru(tpy)(dcbpy)(O)](ClO $\left.)_{4}\right)_{2} .25 \mathrm{mg}$ of [Ru(tpy)(dcbpy) $\left.\left(\mathrm{OH}_{2}\right)\right]\left(\mathrm{ClO}_{4}\right)_{2}(0.03 \mathrm{mmol})$ was dissolved in $10 \mathrm{~mL}$ water and put into ice bath. To the deep brown reaction mixture was added $\left(\mathrm{NH}_{4}\right)_{2}\left[\mathrm{Ce}\left(\mathrm{NO}_{3}\right)_{6}\right](33 \mathrm{mg}, 0.06 \mathrm{mmol})$ solution in $1 \mathrm{~mL}$ of $1 \mathrm{M} \mathrm{HClO}_{4}$ in dropwise. The reaction mixture changed to greenish-yellow and the precipitate was appeared. The product was filtered off and washed with cold water. The crystalline product was filtered and dried in a vacuum dessicator. Yield: $55 \%$. Anal. Calc. for $\mathrm{C}_{27} \mathrm{H}_{19} \mathrm{~N}_{5} \mathrm{Cl}_{2} \mathrm{O}_{13} \mathrm{Ru}$ : C, 40.9; H, 2.41; N, 8.83. Found: C, 42.7; H, 2.58; N, 8.61. ${ }^{1} \mathrm{H}-\mathrm{NMR}$, ppm (200 MHz, $\left.\mathrm{D}_{2} \mathrm{O}\right): \delta-33,-10,0-4,8-10,14-$ $19,32$.

Instrumentations. Routine UV-visible spectra were followed on a Varian Cary 50 UV-visible spectrophotometer. FT IR spectra were obtained on a Varian Scimitar FTS-1000 spectrophotometer on $\mathrm{KBr}$ disc. ${ }^{1} \mathrm{H}-\mathrm{NMR}$ spectra were collected on a Varian Gemini $200 \mathrm{MHz}$ spectrometer. The chemical shifts of ${ }^{1} \mathrm{H}-\mathrm{NMR}$ spectra were presented in parts per million $(\delta)$ and referenced to tetramethylsilane (TMS). Elemental analyses were performed by the analytical laboratory of Basic Science Institute of Korea. Gas Chromatography was performed on a Hewlett-Packard Model 6890 GC equipped with a $6 \mathrm{ft}$. HP-1 column. The oven temperature was maintained at $250^{\circ} \mathrm{C}$. Injector and detector (flame ionization) temperature were maintained at $260^{\circ} \mathrm{C}$. The flow rate (He carrier gas) was $1.0 \mathrm{~mL}$ per minute.

Kinetic Measurements. In acetonitrile, rate constants for the disappearance of $\left[\mathrm{Ru}^{\mathrm{IV}}=\mathrm{O}^{2+}\right]$ were obtained by following absorbance increase at $480 \mathrm{~nm}$ for the $\mathrm{Ru}(\mathrm{II})$ and $\mathrm{Ru}(\mathrm{III})$ products. The wavelength is isosbestic point for the related $\left[\mathrm{Ru}^{\mathrm{II}}-\mathrm{OH}_{2}{ }^{2+}\right] /\left[\mathrm{Ru}^{\mathrm{III}}-\mathrm{OH}^{2+}\right]$ and $\left[\mathrm{Ru}^{\mathrm{II}}-\mathrm{NCCH}_{3}{ }^{2+}\right]$. Plots of $\ln$ $\left|A_{\infty}-A_{\mathrm{t}}\right|$ vs. time were for at least 4 half-lives, and first-order rate constants were calculated on the basis of a least-squares fit to the relation, $\ln \left|A_{\infty}-A_{t}\right|=-k t+\ln \left|A_{\infty}-A_{0}\right|$ where $A_{\infty}$ is the final absorbance at completion of the reaction, $A_{0}$ is the initial absorbance, $A_{\mathrm{t}}$ is the absorbance at time $t$, and $k$ is the first-order rate constant. ${ }^{8} A_{\infty}$ readings were obtained for each run, and data from the first 4 half-lives were used in determining $k$. For practical way we employed the method of pseudo-first-order condition of substrate (benzyl alcohol) in excess to determine $k$ with the experimental rate law $-\mathrm{d}$ $\left[\mathrm{Ru}^{\mathrm{IV}}=\mathrm{O}^{2+}\right] / \mathrm{d} t=k\left[\mathrm{Ru}^{\mathrm{IV}}=\mathrm{O}^{2+}\right][$ substrate $]=k_{\mathrm{obs}}\left[\mathrm{Ru}^{\mathrm{IV}}=\mathrm{O}^{2+}\right]$. The kinetic analysis and reaction conditions in aqueous solution were the same except by following absorbance increase at $490 \mathrm{~nm}$. Purging reactant solutions with Ar before using had no apparent effect on the kinetics.

Catalytic measurements. In a typical catalytic experiment, $0.045 \mathrm{mmol}$ of $\left[\mathrm{Ru}^{\mathrm{II}}-\mathrm{OH}_{2}\right]^{2+}$ dissolved in water reacted with 100 -fold excess of benzyl alcohol with 200 -fold excess of $\mathrm{Ce}(\mathrm{IV})$. The reaction mixture was stirred vigorously for 1 $\mathrm{h}$ and the organic layer was extracted with $\mathrm{CHCl}_{3}$. Chloroform was removed under reduced pressure and the remaining liquid was confirmed as benzaldehyde. TON (catalytic turnover number, $n$ (benzaldehyde) $\left./ n\left(\left[\mathrm{Ru}^{\mathrm{II}}-\mathrm{OH}_{2}\right]^{2+}\right)\right)$ and selectivity ( $n$ (benzaldehyde)/[ $n$ (benzyl alcohol) initial $-n$ (benzyl alcohol) $\left.\left.)_{\text {inal }}\right]\right)$ were determined by ${ }^{1} \mathrm{H}-\mathrm{NMR}$ and gas chromatography.

\section{Results}

Product Analysis and Stoichiometry. The oxidant [Ru (tpy)(dcbpy) $(\mathrm{O})]^{2+}$ was synthesized using the reaction of the corresponding aqua complex with ammonium cerium(IV) nitrate as that reported previously. ${ }^{9}$ Broad resonance peaks for protons directly attached to the central $\mathrm{Ru}$ atom in $[\mathrm{Ru}(\text { tpy })(\mathrm{dcbpy})(\mathrm{O})]^{2+}$ complex in the ${ }^{1} \mathrm{H}-\mathrm{NMR}$ spectrum confirmed the presence of paramagnetic $\mathrm{Ru}(\mathrm{IV})$ complex. ${ }^{10} \mathrm{In}$ the oxidation of benzyl alcohol by $\left[\mathrm{Ru}^{\mathrm{IV}}(\mathrm{tpy})(\mathrm{dcbpy})(\mathrm{O})\right]^{2+}$ complex in acetonitrile the final metal product is diamagnetic $\left[\mathrm{Ru}^{\mathrm{II}}(\mathrm{tpy})(\mathrm{dcbpy})\left(\mathrm{NCCH}_{3}\right)\right]^{2+}$ complex for which $\varepsilon=$ $8000 \mathrm{M}^{-1} \mathrm{~cm}^{-1}$ at $\lambda_{\max }=465 \mathrm{~nm}$. A ${ }^{1} \mathrm{H}-\mathrm{NMR}$ spectrum obtained after allowing equimolar amounts $(10 \mathrm{mM})$ of benzyl alcohol and $[\mathrm{Ru}(\text { tpy })(\mathrm{dcbpy})(\mathrm{O})]^{2+}$ to react in $0.5 \mathrm{~mL}$ of $\mathrm{CD}_{3} \mathrm{CN}$ showed only benzaldehyde and $[\mathrm{Ru}(\mathrm{tpy})(\mathrm{dcbpy})$ $\left.\left(\mathrm{NCCD}_{3}\right)\right]^{2+}$.

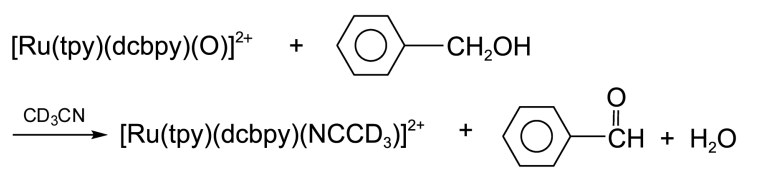

The stoichiometry shown in Eq. (1) was confirmed by integration of the ${ }^{1} \mathrm{H}-\mathrm{NMR}$ resonances. For the reactions between the substituted benzyl alcohols and $[\mathrm{Ru}=\mathrm{O}]^{2+}$ in water and acetonitrile, the same stoichiometries were established by UV-visble, ${ }^{1} \mathrm{H}-\mathrm{NMR}$, and FT IR spectrometers.

Spectral Changes. Figure 1 shows the spectral changes accompanying the oxidation of benzyl alcohol by $[R u(t p y)$ $($ dcbpy $)(\mathrm{O})]^{2+}$ in acetonitrile. In the initial stages of the reaction an isosbestic point appeared at $480 \mathrm{~nm}$ along with a peak at $465 \mathrm{~nm}$. It also showed that a peak around $490 \mathrm{~nm}$ increased in a relatively similar fashion as that at $465 \mathrm{~nm}$ and then slowly decreased. Spectral scans in Figure 2 show solvolysis reaction of $\left[\mathrm{Ru}^{\mathrm{II}}(\right.$ tpy $\left.)(\mathrm{dcbpy})\left(\mathrm{OH}_{2}\right)^{2+}\right]$ in $\mathrm{CH}_{3} \mathrm{CN}$, which has an isosbestic point at $472 \mathrm{~nm}$. 


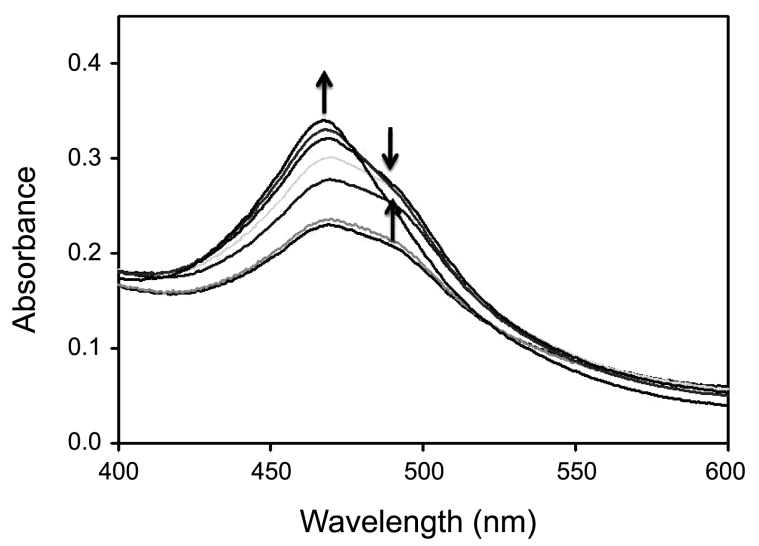

Figure 1. UV-visible spectral changes during the $[\mathrm{Ru}(\mathrm{tpy})(\mathrm{dcbpy})$ (O) $]^{2+}$ oxidation of benzyl alcohol in $\mathrm{CH}_{3} \mathrm{CN}$ : (a) 30 (b) 60 (c) 300 (d) 600 (e) 1200 (f) 1800 (g) $3600 \mathrm{sec}$ after mixing.

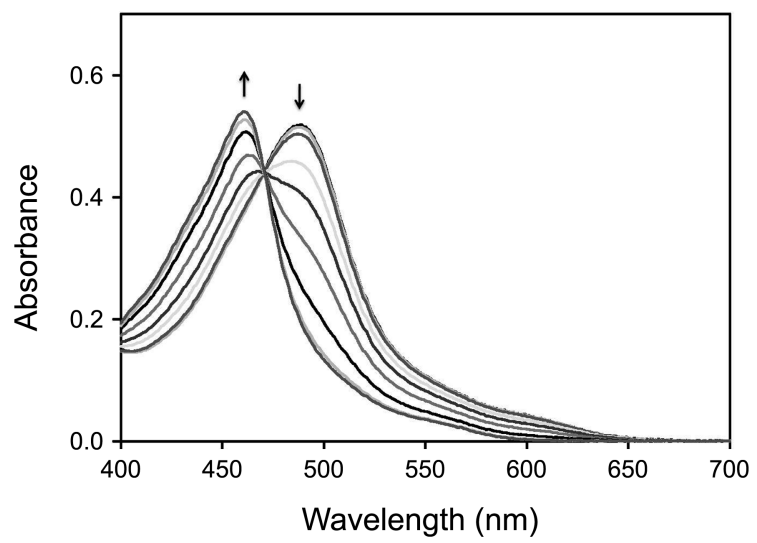

Figure 2. Repetitive UV-visible spectral scans of the solvolysis reaction of $\left[\mathrm{Ru}(\text { tpy })(\mathrm{dcbpy})\left(\mathrm{OH}_{2}\right)\right]^{2+}$ in $\mathrm{CH}_{3} \mathrm{CN}$ : (a) 1 (b) 5 (c) 30 (d) 60 (e) 1200 (f) 2400 (g) 4800 (h) $7200 \mathrm{~min}$ after mixing.

We have already checked that the UV-visible spectrum of independently synthesized $\left[\mathrm{Ru}(\mathrm{tpy})(\mathrm{dcbpy})\left(\mathrm{OH}_{2}\right)\right]^{2+}$ has a peak at $490 \mathrm{~nm}$ as MLCT band, however, that of [Ru(tpy) $(\mathrm{dcbpy})(\mathrm{O})]^{2+}$ is essentially features in the visible region shown in Figure 3.

Therefore, it seems that the reaction occurs in a stepwise fashion via the initial formation of $\left[\mathrm{Ru}-\mathrm{OH}_{2}\right]^{2+}$ and subsequently solvolyzed by acetonitrile to give $\left[\mathrm{Ru}-\mathrm{NCCH}_{3}\right]^{2+}$.

$[\mathrm{Ru}(\text { tpy })(\text { dcbpy })(\mathrm{O})]^{2+}+\mathrm{PhCH}_{2} \mathrm{OH} \rightarrow\left[\mathrm{Ru}(\text { tpy })(\text { dcbpy })\left(\mathrm{OH}_{2}\right)\right]^{2+}+\mathrm{PhCHO}$

$\left[\mathrm{Ru}(\text { tpy })(\text { dcbpy })\left(\mathrm{OH}_{2}\right)\right]^{2+}+\mathrm{CH}_{3} \mathrm{CN} \rightarrow\left[\mathrm{Ru}(\text { tpy })(\text { dcbpy })\left(\mathrm{NCCH}_{3}\right)\right]^{2+}+\mathrm{H}_{2} \mathrm{O}$

Similar spectral changes were observed for all of the benzyl alcohols listed in Table 1 .

Kinetics. The observed rate constant for benzyl alcohol oxidation by $\left[\mathrm{Ru}^{\mathrm{IV}}=\mathrm{O}\right]^{2+}$ in acetonitrile is linearly dependent on the concentration of the substrate, which is consistent with the experimental rate law and Eq. (1). The kinetics of both the initial fast redox and subsequent slow solvolysis steps were studied by using UV-visible spectrometer. Rate

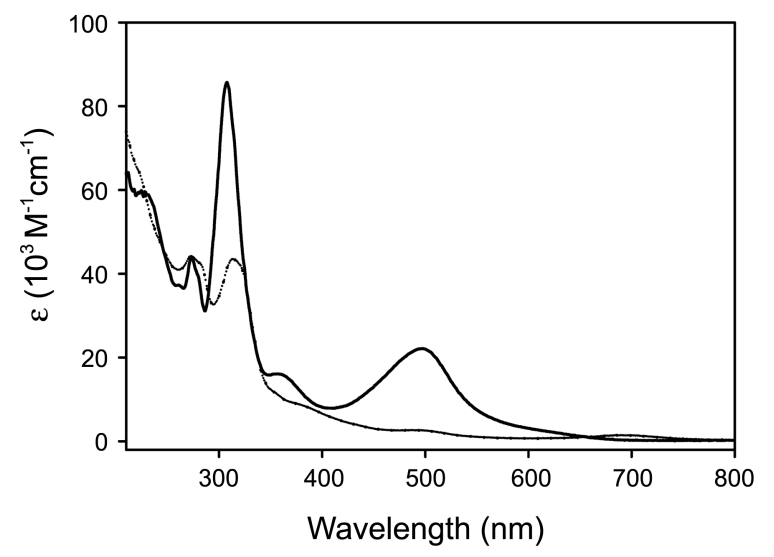

Figure 3. UV-visible spectrum of $[\mathrm{Ru}(\text { tpy })(\mathrm{dcbpy})(\mathrm{O})]^{2+}(\cdots \cdots \cdot)$ and $\left[\mathrm{Ru}(\text { tpy })(\mathrm{dcbpy})\left(\mathrm{OH}_{2}\right)\right]^{2+}(-)$ in water.

Table 1. Rate constants for the oxidation of benzyl alcohol, its derivatives, and benzyl alcohol- $\alpha, \alpha-d_{2}$ by $[\operatorname{Ru}(\text { tpy })(\operatorname{dcbpy})(\mathrm{O})]^{2+}$ in $\mathrm{CH}_{3} \mathrm{CN}$

\begin{tabular}{ccc}
\hline Substrate & $t$, & $k^{a}, \mathrm{M}^{-1} \mathrm{~s}^{-1}$ \\
\hline benzyl alcohol & $20.0( \pm 0.1)$ & $1.65( \pm 0.01)$ \\
benzyl alcohol & $24.0( \pm 0.2)$ & $1.82( \pm 0.09)$ \\
benzyl alcohol & $30.0( \pm 0.1)$ & $2.20( \pm 0.06)$ \\
benzyl alcohol & $36.0( \pm 0.5)$ & $2.44( \pm 0.05)$ \\
benzyl alcohol & $40.0( \pm 0.5)$ & $2.80( \pm 0.11)$ \\
4-nitro benzyl alcohol & $20.0( \pm 0.1)$ & $1.67( \pm 0.02)$ \\
4-methyl benzyl alcohol & $20.0( \pm 0.1)$ & $2.32( \pm 0.01)$ \\
2-ethyl benzyl alcohol & $20.0( \pm 0.1)$ & $2.77( \pm 0.13)$ \\
benzyl alcohol- $\alpha, \alpha-d_{2}$ & $20.0( \pm 0.1)$ & $3.03( \pm 0.16) \times 10^{-2}$ \\
benzyl alcohol- $\alpha, \alpha-d_{2}$ & $24.0( \pm 0.2)$ & $4.00( \pm 0.01) \times 10^{-2}$ \\
benzyl alcohol- $\alpha, \alpha-d_{2}$ & $30.0( \pm 0.1)$ & $4.91( \pm 0.30) \times 10^{-2}$ \\
benzyl alcohol- $\alpha, \alpha-d_{2}$ & $36.0( \pm 0.5)$ & $5.90( \pm 0.21) \times 10^{-2}$ \\
benzyl alcohol- $\alpha, \alpha-d_{2}$ & $40.0( \pm 0.5)$ & $6.97( \pm 0.23) \times 10^{-2}$ \\
\hline Averac of
\end{tabular}

${ }^{a}$ Average of three kinetic runs at four different concentration of substrates.

constant data for the oxidation of benzyl alcohol and its derivatives in $\mathrm{CH}_{3} \mathrm{CN}$ are summarized in Table 1 .

In solutions relatively dilute in benzyl alcohol the reactions are first-order in oxidant and first- order in benzyl alcohol. The solvolysis rate was independent of the concentration of added benzyl alcohol with half-life of $2.7 \mathrm{~h}$.

Activation Parameters. In Table 2 are listed activation parameters for the oxidation of benzyl alcohol by $[\mathrm{Ru}(\mathrm{tpy})$ $($ dcbpy $)(\mathrm{O})]^{2+}$ obtained from plots of $-\ln (k / T)$ vs. $1 / T$ in Figure 4 over the temperature range of $15-40{ }^{\circ} \mathrm{C}$, which gave $\Delta H^{*}=4.3( \pm 0.1) \mathrm{kcal} / \mathrm{mol}, \Delta S^{*}=-22( \pm 1) \mathrm{eu}$, and $E_{a}=4.9$ $( \pm 0.1) \mathrm{kcal} / \mathrm{mol}$.

Kinetic Isotope Effects. H/D kinetic isotope effects for the oxidation of benzyl alcohol and benzyl alcohol- $\alpha, \alpha-d_{2}$ by $[\mathrm{Ru}(\mathrm{tpy})(\mathrm{dcbpy})(\mathrm{O})]^{2+}$ in acetonitrile are also listed in Table 2. To aid dissociation of water insoluble substrates some reactions were performed in acetone/water mixture. Results for solvent kinetic isotope effects are also given in Table 2. 
Table 2. Summary of kinetic and thermodynamic parameters for the oxidation of benzyl alcohol and deuteriated benzyl alcohol by [Ru(tpy) $(\mathrm{dcbpy})(\mathrm{O})]^{2+}\left(\left[\mathrm{Ru}^{\mathrm{IV}}=\mathrm{O}\right]^{2+}\right)$

\begin{tabular}{|c|c|c|c|c|c|}
\hline Reaction & Medium $^{a}$ & $k^{b}, \mathrm{M}^{-1} \mathrm{~s}^{-1}$ & $\Delta H^{*}, \mathrm{kcal} / \mathrm{mol}$ & $\Delta S^{\star}$, eu & $k_{\mathrm{H}} / k_{\mathrm{D}}$ \\
\hline$\left[\mathrm{Ru}^{\mathrm{IV}}=\mathrm{O}\right]^{2+}+\bigcirc-\mathrm{CH}_{2} \mathrm{OH}$ & $\mathrm{CH}_{3} \mathrm{CN}$ & 1.65 & 4.3 & -22 & \\
\hline$\left[\mathrm{Ru}^{\mathrm{IV}}=\mathrm{O}\right]^{2+}+\bigcirc-\mathrm{CD}_{2} \mathrm{OH}$ & $\mathrm{CH}_{3} \mathrm{CN}$ & $3.03 \times 10^{-2}$ & 6.6 & -22 & 54.5 \\
\hline$\left[\mathrm{Ru}^{\mathrm{IV}}=\mathrm{O}^{2+}+\bigcirc-\mathrm{CH}_{2} \mathrm{OH}\right.$ & acetone $/ \mathrm{H}_{2} \mathrm{O}$ & 1.97 & & & \\
\hline$\left[\mathrm{Ru}^{\mathrm{IV}}=\mathrm{O}^{2+}+\bigcirc-\mathrm{CH}_{2} \mathrm{OH}\right.$ & acetone- $d_{6} / \mathrm{D}_{2} \mathrm{O}$ & 1.92 & & & 1.03 \\
\hline
\end{tabular}

${ }^{a}$ Acetone/ $\mathrm{H}_{2} \mathrm{O}$ refers to a $1 / 1$ (by volume) solution. ${ }^{b}$ Average of four different determinations at a single temperature $(t=20)$.

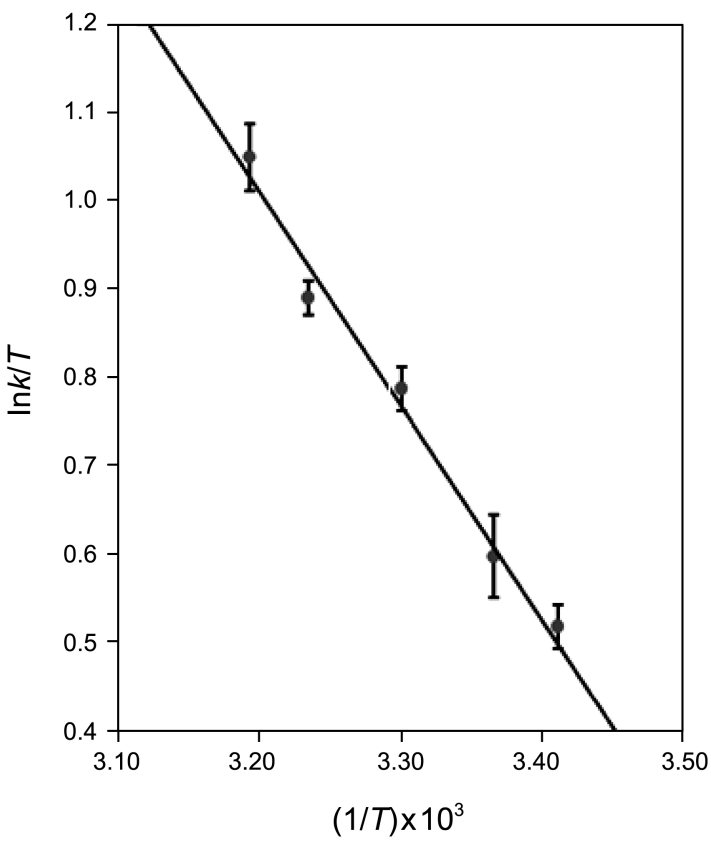

Figure 4. Plot of $1 / T v s .-\ln (k / T)$ for the benzyl alcohol oxidation by $[\mathrm{Ru}(\text { tpy })(\text { dcbpy })(\mathrm{O})]^{2+}$ in $\mathrm{CH}_{3} \mathrm{CN}$.

\section{Discussions}

Mechanistic Considerations. The magnitude of the $k_{\mathrm{H}} / k_{\mathrm{D}}$ isotope effect points to an important role for the $\alpha \mathrm{C}-\mathrm{H}$ bond in the redox step as have been reported for the reaction of between $\left[\mathrm{Ru}(\mathrm{bpy})_{2}(\mathrm{py})(\mathrm{O})\right]^{2+}$ (bpy $=2,2^{\prime}$-bipyridine; py = pyridine) and a series of alcohols, ${ }^{11}$ hydroquinone, ${ }^{12}$ and $\left[\mathrm{Ru}(\mathrm{bpy})_{2}(\mathrm{py})\left(\mathrm{OH}_{2}\right)\right]^{2+}$. $^{13}$ The available spectral evidences including rate law and product analyses indicate that the dominant pathway for the oxidation of benzyl alcohol and its derivatives by $\left[\mathrm{Ru}^{\mathrm{IV}}(\mathrm{tpy})(\mathrm{dcbpy})(\mathrm{O})\right]^{2+}$ complex appears to a two-electron, hydride transfer. Experimental and computation results to point hydride transfer mechanism using $\mathrm{NAD}^{+}$have been well established. ${ }^{14}$ The mechanisms can be an initial pre-association step between the oxidant and the substrate, which then undergoes most probably a redox step

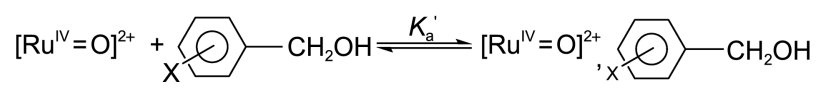

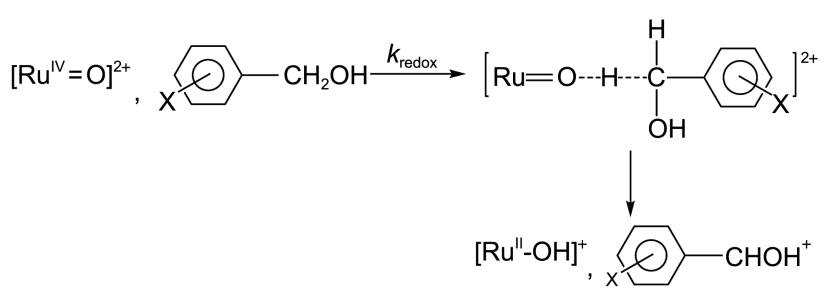

followed by separation and rapid proton equilibration

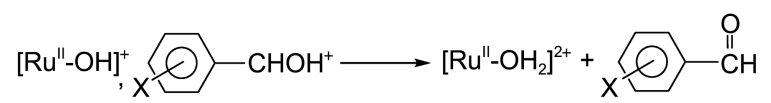

Therefore it is reasonable that combination of the association constant, $K_{\mathrm{a}}^{\prime}$, with the rate constant of the redox step, $k_{\text {redox }}$ gives the experimentally measured rate constant. $K_{\mathrm{a}}^{\prime}$ is the product of a $K_{\mathrm{a}}$-like term and an orientation factor reflecting the fraction of association complexes. ${ }^{11 \mathrm{~b}}$ The negative entropies of activation have their origins in the association constant through the association and orientational demands of the reactants. Given an intimate interaction between $\left[\mathrm{Ru}^{\mathrm{IV}}=\mathrm{O}\right]^{2+}$ and benzyl alcohol, it is not simple to apply the statistically derived association constant as calculated by the Eigen-Fuoss equation. ${ }^{15}$

The rate of oxidation of benzyl alcohol derivatives by $\left[\mathrm{Ru}^{\mathrm{IV}}=\mathrm{O}\right]^{2+}$ varies by changing in structure of the alcohol shown in Table I. Data in Table II show that the secondorder rate constant in water slightly increases in comparison with that in acetonitrile. Although it is not conclusive, electrondonating substituents increase the rate of oxidation. It also implies the transition state has an electron-deficient center.

The question remains whether the redox step involves 2 equiv and the direct production of $\left[\mathrm{Ru}^{\mathrm{II}}-\mathrm{OH}_{2}\right]^{2+}$ and benzaldehyde via a two-electron pathway

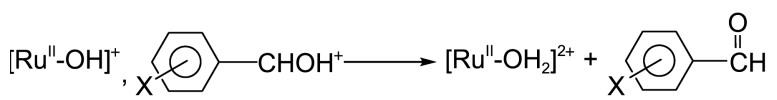

followed by rapid proton equilibration, or an initial oneelectron step

$$
\left[\mathrm{Ru}^{\mathrm{IV}}=\mathrm{O}^{2+}+\underset{x}{ }-\mathrm{CH}_{2} \mathrm{OH} \longrightarrow\left[\mathrm{Ru}^{\mathrm{III}}-\mathrm{OH}_{2}\right]^{2+}+\underset{\mathrm{C}}{ } \dot{\mathrm{C}} \mathrm{HOH}\right.
$$

followed by oxidation of radical by $\left[\mathrm{Ru}^{\mathrm{IV}}=\mathrm{O}\right]^{2+},\left[\mathrm{Ru}^{\mathrm{III}}-\mathrm{OH}\right]^{2+}$, or $\mathrm{O}_{2}$.

The spectral changes in Figure 1 are all consistent with the 
Mechanism A (two-electron)

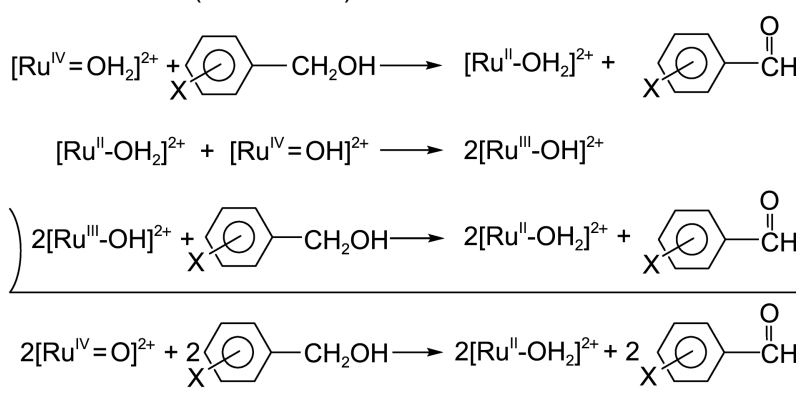

Mechanism B (one-electron)

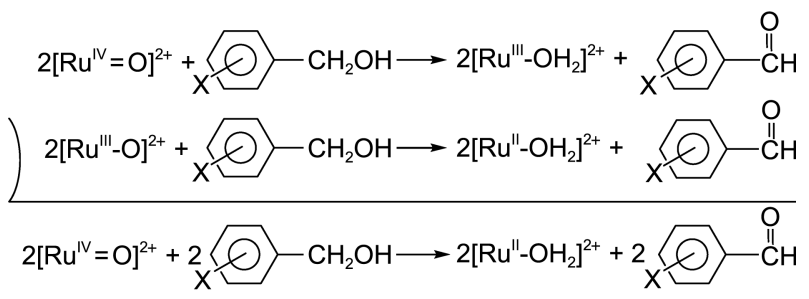

Scheme 1

mechanisms illustrated in Scheme 1. Mechanism A shows that the initial redox step, $k_{\text {redox }}$, is the rate of a net twoelectron step to give $\mathrm{Ru}(\mathrm{II})$ while in mechanism $\mathrm{B}, k_{\text {redox }}$ represents the rate of of a one-electron step to give $\mathrm{Ru}(\mathrm{III})$. The two mechanisms can be distinguishable by observing whether the initial product is $\mathrm{Ru}(\mathrm{II})$ or $\mathrm{Ru}(\mathrm{III})$. However, both their absorption spectra of $\mathrm{Ru}(\mathrm{II})$ and $\mathrm{Ru}(\mathrm{III})$ are not very distinct and since $\left[\mathrm{Ru}^{\mathrm{II}}-\mathrm{OH}_{2}\right]^{2+}$, once formed, undergoes a rapid comproportionation with $\left[\mathrm{Ru}^{\mathrm{IV}}=\mathrm{O}\right]^{2+}$ to give $2\left[\mathrm{Ru}^{\mathrm{III}}\right.$ $\mathrm{OH}]^{2+}$, therefore it is not easy to draw a sharp line between these two pathways. ${ }^{11 a}$

There is no observed rate dependence on the presence or absence of $\mathrm{O}_{2}$, which might rule out one-electron hydrogen atom abstraction pathway. Considering an initial one-electron step followed by a second, rapid, one-electron transfer before the radical can separate in solution, we can't exclude one-electron transfer pathway. However, the mechanism certainly suffers from the instability of the initial product. ${ }^{12}$

$$
\begin{aligned}
& {\left[\mathrm{Ru}^{\mathrm{iv}}=\mathrm{O}^{2+},\right.}
\end{aligned}
$$

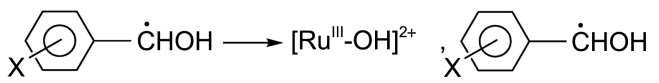

Kinetic Isotope Effects. The observed high $k_{\mathrm{H}} / k_{\mathrm{D}}$ isotope effect in the oxidation of benzyl alcohol indicates that $\alpha \mathrm{C}-\mathrm{H}$ bond breaking is an important rate-determining step. Isotope effects of this unusual size are often attributed to tunneling effect and have been observed in some oxidants including $[\mathrm{Ru}=\mathrm{O}]^{2+}$ systems, although the magnitude of the isotope effects has not so far been fully explained. ${ }^{16}$

However, it is important to note that for benzyl alcohol the kinetic isotope effect at lower temperatures is larger and temperature dependent over the temperature range studied, with $\Delta H^{\sharp}=4.3 \mathrm{kcal} / \mathrm{mol}$ and $\Delta S^{\sharp}=-22 \mathrm{eu}\left(E_{\mathrm{a}}=4.9 \mathrm{kcal} /\right.$ mol) for $\mathrm{C}_{6} \mathrm{H}_{5} \mathrm{CH}_{2} \mathrm{OH}$ and $\Delta H^{*}=6.6 \mathrm{kcal} / \mathrm{mol}$ and $\Delta S^{\sharp}=-22$ eu $\left(E_{\mathrm{a}}=7.2 \mathrm{kcal} / \mathrm{mol}\right)$ for $\mathrm{C}_{6} \mathrm{H}_{5} \mathrm{CD}_{2} \mathrm{OH}$, Kinetic isotope effects are the direct manifestation of the quantum nature of matter and H/D isotopic exchange does not affect the potential energy surface and the electronic energy levels. Only molecular vibrations can change reaction rates and mechanisms. Maximum kinetic isotope effects might be observed at low temperatures where transitions are dominant by vibrational levels close to $v=0$.

With benzyl alcohol, similar oxidation experiments were performed in $\left(\mathrm{CH}_{3}\right)_{2} \mathrm{CO} / \mathrm{H}_{2} \mathrm{O}$ solutions, though the rates were slightly higher in aqueous solution than in acetonitrile, but they were unaffected compared to $\left(\mathrm{CD}_{3}\right)_{2} \mathrm{CO} / \mathrm{D}_{2} \mathrm{O}$. It suggests that $\mathrm{O}-\mathrm{H}$ bond breaking is not an important ratedetermining step.

Implication for Catalysis. Large numbers of transition metal complexes show their catalytic activity toward benzyl alcohol and its derivatives. ${ }^{5 b}$ In aquous solution $\mathrm{Ce}(\mathrm{IV})$ oxidizes the aqua complexes to give the oxo ones as shown by spectrophotometric titrations. As we have already established, the oxidation of benzyl alcohols by $\left[\mathrm{Ru}^{\mathrm{IV}}=\mathrm{O}\right]^{2+}$ resulted in the formation of $\left[\mathrm{Ru}^{\mathrm{II}}-\mathrm{OH}_{2}\right]^{2+}$ and benzaldehydes. We can combine these two systems as illustrated followings:

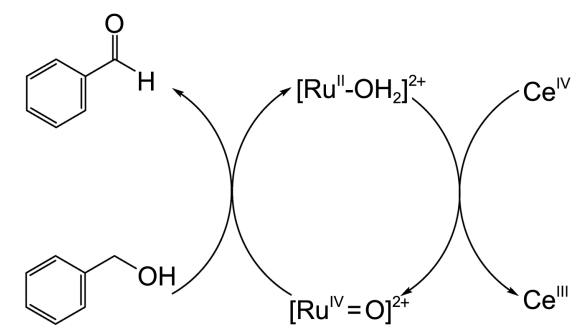

From the reaction of excess benzyl alcohol with $[\mathrm{Ru}($ tpy) (dcbpy) $\left.\left(\mathrm{OH}_{2}\right)\right]^{2+}$ and one-electron co-oxidant $\mathrm{Ce}(\mathrm{IV})$ in excess, TON of 70 conversion in $80 \%$ selectivity was confirmed and was analyzed by ${ }^{1} \mathrm{H}-\mathrm{NMR}$ and gas chromatography, which our complex has been of value as catalyst.

\section{References}

1. (a) Gong, J. I.; Mullins, C. B. Acc. Chem. Res. 2009, 42, 1063. (b) Hu, L.; Cao, X.; Yang, J.; Li, M.; Hong, H.; Xu, Q.; Ge, J.; Wang, L.; Lu, J.; Chen, L.; Hu, H. Chem. Commun. 2011, 47, 1303 and references therein.

2. (a) Meyer, T. J.; Huynh, M. H. V. Inorg. Chem. 2003, 42, 8140. (b) Zhang, J.; Liang, J.-L.; Sun, X.-R.; Zhou, H.-B.; Zhu, N.-Y.; Chan, P. W. H.; Che, C.-M. Inorg. Chem. 2005, 44, 3942. (c) Waidmann, C. R.; Zhou, X.; Tsai, E. A.; Kaminsky, W.; Hrovat, D. A.; Borden, W. T.; Mayer, J. M. J. Am. Chem. Soc. 2009, 131, 4729. (d) Karmee, S. K.; Greiner, L.; Kraynov, A.; Muller, T. E.; Niemeijer, B.; Leitner, W. Chem. Commun. 2010, 46, 6705.

3. (a) Wasylenko, D. J.; Ganesamoorthy, C.; Koivisto, B. D.; Henderson, M. A.; Berlinguette, C. P. Inorg. Chem. 2010, 49, 2202. b) Chen, Z.; Concepcion, J. J.; Hu, X.; Yang, W.; Hoertz, P. G.; Meyer, T. J. Proc. Nat. Acad. Sci. 2010, 107, 7225.

4. (a) Gratzel, M. Acc. Chem. Res. 2000, 33, 269. (b) Wang, M.; Liu, J.; Cevey-Ha, N.; Moon, S.-J.; Liska, P.; Humphry-Baker, R.; Moser, J.-E.; Gratzel, C.; Wang, P.; Zakeeruddin, S.; Gratzel, M. Nano Today 2010, 5, 169.

5. (a) Hornstein, B. J.; Dattelbaum, D. M.; Schoonover, J. R.; Meyer, 
T. J. Inorg. Chem. 2007, 46, 8139. (b) Liu, L.; Yu, M.; Wayland, B. B.; Fu, X. Chem. Commun. 2010, 46, 6353 and references therein.

6. Perrin, D. D.; Armarego, W. L. F. Purification of Laboratory Chemicals, $3^{\text {rd }}$ ed.; Pergamon Press: New York, 1988

7. Seok, W. K.; Gupta, A. K.; Roh, S.-J.; Lee, W.; Han, S.-H. Bull. Korean Chem. Soc. 2007, 28, 1311.

8. Moore, J. W.; Pearson, R. G. Kinetics and Mechanisms, $3^{\text {rd }}$ ed.; John Wiley \& Sons: New York, 1981; p 71.

9. (a) Bales, B. C.; Brown, P.; Dehestani, A.; Mayer, J. M. J. Am. Chem. Soc. 2005, 127, 2822. (b) Seok, W. K.; Meyer, T. J. Inorg. Chem. 2005, 44, 3931.

10. Dobson, J. C.; Helms, J. H.; Doppelt, P.; Sullivan, B. P.; Hatfield, W. E.; Meyer, T. J. Inorg. Chem. 1989, 28, 2200.

11. (a) Thompson, M. S.; Meyer, T. J. J. Am. Chem. Soc. 1982, 104, 4106. (b) Roecker, L.; Meyer, T. J. J. Am. Chem. Soc. 1987, 109, 746.
12. Binstead, R. A.; McGuire, M. E.; Dovletoglou, A.; Seok, W. K.; Meyer, T. J. J. Am. Chem. Soc. 1992, 114, 173.

13. Binstead, R. A.; Moyer, B. A.; Samuels, G. J.; Meyer, T. J. J. Am. Chem. Soc. 1981, 103, 2897.

14. (a) Kreevoy, M. M.; Kotchevar, A. T. J. Am. Chem. Soc. 1990, 112, 3579. (b) Lee, I.-S. H.; Chow, K.-H.; Kreevoy, M. M. J. Am. Chem. Soc. 2002, 124, 7735.

15. Sutin, N. Acc. Chem. Res. 1982, 15, 275.

16. (a) Anderson, S. N.; Cooksey, C. J.; Holton, S. G.; Johnson, M. D. J. Am. Chem. Soc. 1980, 102, 2312. (b) Bryant, J. R.; Mayer, J. M. J. Am. Chem. Soc. 2003, 125, 10351. (c) Lam, W. W. Y.; Yiu, S.M.; Yiu, D. T. Y.; Lau, T.-C.; Yip, W.-P.; Che, C.-M. Inorg. Chem. 2003, 42, 8011. (d) Mezer, A.; Friedman, R.; Noivirt, O.; Nachliel, E.; Gutman, M. J. Phys. Chem. B 2005, 109, 11379. (e) Jeong, Y. J.; Kang, Y.; Han, A.-R.; Lee, Y.-M.; Kotani, H.; Fukuzumi, S.; Nam, W. Angew. Chem. Int. Ed. 2008, 47, 7321. 